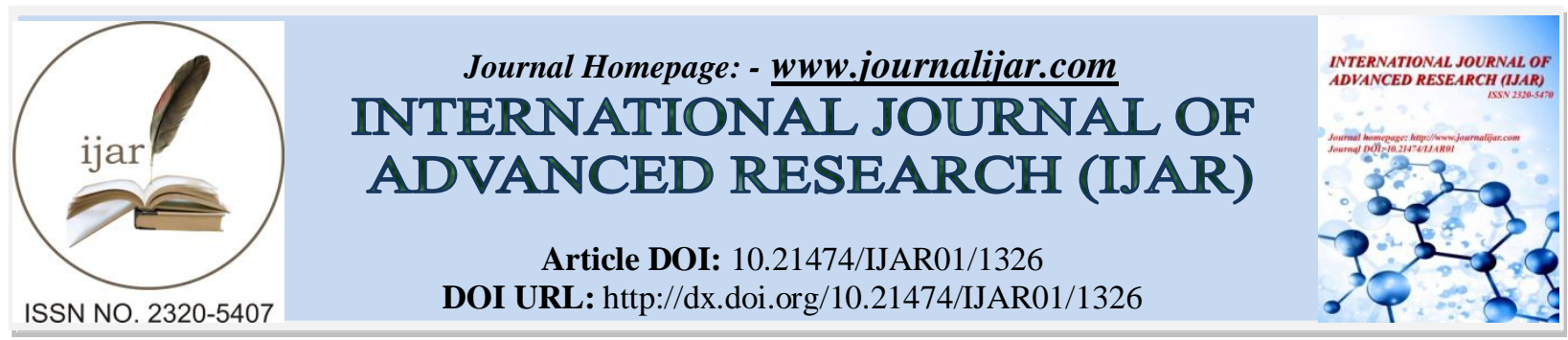

RESEARCH ARTICLE

\title{
AN OPINION SURVEY ON ENGLISH AS A MEDIUM OF INSTRUCTION AT BENGALI-MEDIUM JUNIOR HIGH SCHOOL LEVEL IN WEST BENGAL.
}

\author{
Partha Ghosh ${ }^{1}$ and Subhalakshmi Nandi ${ }^{2}$. \\ 1. Assistant Professor, Department of Education, Bankura University, Bankura, W.B. \\ 2. Professor, Department of Education,University of Kalyani, Kalyani, Nadia, W.B.
}

Manuscript Info
Manuscript History
Received: 12 June 2016
Final Accepted: 22 July 2016
Published: August 2016
Key words:-
Medium of instruction; Bengali-medium
schools; Opinionnaire.

\section{Abstract}

Present study was a descriptive field survey with a researcher-made opinionnaire in order to investigate whether students of Bengalimedium schools under WBBSE prefer English as the medium of instruction and to vindicate the nature of such preferences. The target population of the study was the junior high school students of Bengali - medium schools under the curriculum of WBBSE in the state of West Bengal. Convenience sampling technique under non-probability sampling method was used in order to make a sample size $(\mathrm{N})$ of 850 students in total. Two sub samples were formed with equal number of participants, namely, $n_{1}=425$ from rural districts and $n_{2}=425$ from urban city. Findings of the study revealed that irrespective of sociocultural differences and divergences of locality, participant students preferred English as medium of classroom instruction. The study finally determined the nature of such preferences.

Copy Right, IJAR, 2016,. All rights reserved.

\section{Introduction:-}

Language is the medium of thought. Every community has its own language as all communities need it in essence basically for informal communication and secondarily for formal education, instruction and training in order to expand the community's literate fraternity. This is the first language that a person learns when s/he is a baby; this is one's native language. This is the language that is learned by children first from parents and passed from one generation to the next. This is called 'natural language', the 'mother tongue'. If asked like how many languages are there in the world, it seems a stupid question. The answer might be 'uncountable'. Actually, the question of how many languages there in the world has always been surrounded by uncertainty. While it might be assumed that linguists have a definite idea of the exact number, as it turns out, there are many different reasons why determining a full count of world languages is so difficult. And it can't simply be attributed to the fact that there are still parts of the world that have not yet been fully explored, such as the Amazon and the highlands of New Guinea (World languages, 2014). If we deal with the questions like - What is the position of English language in the world? Is English a global language? 'The History of English' shows that "a global language essentially refers to a language that is learned and spoken internationally, and is characterized not only by the number of its native and second language speakers, but also by its geographical distribution, and its use in international organizations and in diplomatic relations. A global language acts as a "lingua franca", a common language that enables people from diverse backgrounds and ethnicities to communicate on a more or less equitable basis," and that "English is the nearest thing there has ever been to a global language. Its worldwide reach is much greater than anything achieved historically by Latin or French, and there has never been a language as widely spoken as English. Many would 
reasonably claim that, in the fields of business, academics, science, computing, education, transportation, politics and entertainment, English is already established as the de facto lingua franca" (The History of English, 2011). Another important question is - Is English an international language? An eminent researcher, Sharifian (2009) viewed that "In the last few decades, there has been a growing interest in the development of English as an international language (EIL). EIL implies a new way of communication across different nationalities and cultures through the medium of a common language. The emergence of EIL and World Englishness is undoubtedly linked to the phenomenon of globalization and it is often stigmatized in the traditional ELT context, which is still dominated by native-speaker standards."

Present day, many researchers abroad have conducted studies on these burning issues. Lueg and Lueg (2015) reported that taking a Bourdieusian perspective, they analyzed the relevance of social background and capital for choosing English as a medium of instruction (EMI) focusing on students with a non-native English-language background in a business school setting. Their findings revealed that students from higher social strata are much more likely to choose EMI. As suggested by the Bourdieusian perspective, this relationship is not directly observable but operates through hidden mechanisms, such as cultural capital (relative English proficiency) and a better sense of gaming and positioning (career orientation). Business students from the lowest stratum self-select against EMI due to a pronounced fear of failure despite their awareness that EMI leads to higher employability. They demanded that their findings supported the successful introduction of EMI while ensuring social equality. Similarly, Lueg (2015) presented a paper which discussed the possible policies to handle English as a medium of instruction for higher education (HE) in Denmark. It summarized the de-facto status of the institutionalization of English as a lingua franca and EMI in Europe and relates the findings to the status quo of the academic and political discussion about EMI in Denmark. This discussion was classified into three typical approaches: the progressive, the conservative, and the radical conservative. The distinction was supplemented with the results of the author's own recent study on EMI and the introduction of a fourth perspective: the 'cautiously progressive perspective'. This perspective supported further introduction of EMI, on condition that careful attention must be given to the way EMI is implemented. Possible lines of reactions, implications, and recommendations were introduced. Lo and Lo (2014) conducted a Meta analysis of the Effectiveness of English-Medium Education in Hong Kong. According to them, "To facilitate second language learning, it has become increasingly popular to use a second language as the medium of instruction for content subjects for majority language students. Although numerous research studies have shown the advantages of such kind of programs in North America and Europe, those investigating English as the Medium of Instruction (EMI) schools in Hong Kong yielded inconclusive results. This meta-analysis is the first attempt to synthesize the research evidence on EMI education in Hong Kong since 1970. Based on 24 studies, this meta-analysis shows that students in EMI secondary schools were more proficient in second language and performed better on measures of affective variables. Yet their learning in other content subjects suffered. The differences between the effectiveness of EMI education in Hong Kong and that of similar programs in other contexts will be discussed, thereby illuminating second language acquisition theories and bilingual education."

Literature review so far conducted by the researchers exposed a reality that Indian educational researchers were little interested to this field as noteworthy researches were hard to find in different reputed journals and publications. This was one of the reasons behind the identification of this researchable problem.

\section{Emergence of the problem:-}

In India, English language gets the parallel status with Hindi which is the national language in the sectors of government offices, judiciary systems and diplomatic circles. But in Indian higher Education, English is the only official language. However, in Indian school education system English earns the status of first language in the curricula under a few number of boards and councils, especially which are controlled by the Central government but in the curricula under state-run boards and councils, English is almost treated as second language.

In the most state-aided secondary schools of West Bengal, even in exclusively government schools, English is taught as a skill subject aiming at developing communicating power for everyday life though the academicians are very much dissatisfied with the end results of the curricular experiences in regard to communicative English. Moreover, English is not taught as a knowledge subject that also has some objectives for generating appreciation for the subject. In these schools, English is taught as a compulsory subject from the primary level but the status it has been given is the 'second language'. Consequently, it has been gradually realized by the academics that our future generation is developing a bit handicapped in order to compete with the modern day global society which in every sphere of ICT-bound life demands English as a language for social interaction, academic discourse, economic 
transaction as well as global reciprocity. Side by side, another important visualization is that if such students have been provided with a handful of English environment in the formal classroom through compulsory English medium instruction for all the school subjects under curriculum then they will be able to take meaningful participation at least in the latter academic and vocational field. With these objectives in view, the Ministry of Education, Government of West Bengal thought to introduce 'English-medium' classroom instruction at the secondary level of all the Bengali-medium schools. The consequent effects of this proposal were media news, social discourses from every corner of the society and the obvious for-against debates.

Under the above backdrop, the present researchers intended to study the problem through the survey of opinion of one of the most crucial stakeholders of the issue - the students who were the target concerns of their parents, teachers and the government.

\section{Objectives of the study:-}

Present study aimed at fulfilling the following objectives:

- To investigate whether the students of Bengali medium schools under WBBSE prefer English as the medium of instruction or not.

- To vindicate the nature of such preferences.

\section{Research design:-}

The study followed the strategy of Descriptive Quantitative Research through opinion survey with the help of a researcher made questionnaire in order to test the following research hypothesis and to vindicate the nature of the determined preferences.

Hypothesis:- There is a significant difference between Bengali - medium rural and urban junior high school students under WBBSE in regard to their preference for English as a medium of instruction.

Population and Sample:- The target population of the study was the junior high school students of Bengali medium schools under the curriculum of WBBSE in the state of West Bengal. The study population consisted of the aforesaid students particularly from the rural district-based schools in West Bengal as well as from Kolkata, the only metropolitan city of West Bengal.

Convenience sampling technique under non-probability sampling method was used in order to make a sample size (N) of 850 students in total. Homogeneity within the sample was maintained with the help of age (14+ years) and education (studying in class IX). Two sub samples were formed with equal number of participants, namely, $\mathrm{n}_{1}=425$ from rural districts and $\mathrm{n}_{2}=425$ from urban city. Accordingly the two sub samples revealed the heterogeneous nature in regard to socio - cultural background (rural and urban Bengalee Hindu families) and school environment (government - aided district-based rural and Kolkata-based urban secondary schools). Gender effectiveness on the issue had not been considered in the present study. Thus, the sample had not been stratified on the basis of gender.

Tool: A researcher made opinionnaire was used for data collection. Following the conventional procedure, construct validity of the questionnaire was determined by the three experts from the field of Education. Split-half reliability of the test was determined as .89. The tool was not standardized through 'Item-analysis'. First of all, 5 dimensions covering the said issue were settled and chalked out with the help of experts. These were like fluency in speech, helpful for higher education, easy worldwide communication, boosting self esteem and conflict with the mother tongue. The questionnaire consisted of statements by first person. Under each dimension, 06 items were prepared. In this way the final form of the questionnaire contained ( $05 \times 06) 30$ items. Two response patterns, namely, 'yes' and 'no' against each item indicated the participant's liking for the English medium and his/her disliking against such respectively. 01 score was given to 'yes' response and 00 to 'no' response so that the score rationale pointed to high score for preference to English medium instruction by the students of Bengali medium schools. Accordingly, reverse scoring was done for the negative items, namely, the items 19, 20, 25 and 29.

Data collection:- With prior appointment data were collected from aforesaid 850 students of 15 government-aided (07 district-based rural and 08 Kolkata-based urban) Bengali-medium secondary schools selected at random. Data were collected by the researcher made opinionnaire after establishing rapport with the students and let them feel the seriousness of their responses. Each session was followed by an unstructured interview of 10 to 15 minutes with 
the group of students for any clarification of data in future. After data collection, data were processed, tabulated and statistically analyzed in order to arrive at conclusions.

\section{Results:-}

For the verification of research hypothesis, ' $t$ ' value was calculated between the total score of responses of $n_{1}=425$ from rural districts and those of $\mathrm{n}_{2}=425$ from urban city. The value $(\mathrm{t}=1.7686)$ was found 'not significant' (Table 1). This statistically insignificant $t$ value indicated that there was no significant difference between responses of students from rural districts and those from urban city in regard to the preference for English as medium of instruction. Therefore, the research hypothesis was rejected, and henceforth, the total sample $(\mathrm{N}=850)$ was treated as a single group.

Table 1:- Difference between means of responses of two groups of participants.

\begin{tabular}{|l|l|l|l|l|}
\hline Variables & Mean & Mean difference & $\mathrm{SE}_{\mathrm{D}}$ & $\mathrm{t}$ \\
\hline $\begin{array}{l}\text { Rural students }\left(\mathrm{n}_{1}\right. \\
=425)\end{array}$ & $\mathbf{2 0 . 5}$ & $\mathbf{0 . 7 3}$ & $\mathbf{1 . 7 6 8 6}$ \\
\hline $\begin{array}{l}\text { Urban students }\left(\mathrm{n}_{2}\right. \\
=425)\end{array}$ & 21.23 & & \\
\hline \multicolumn{3}{|c|}{ not significant } \\
\hline
\end{tabular}

To vindicate the nature of such preference, item-wise percentage analysis was done and accordingly, the most preferred item (Rank 1) and the least preferred item (Rank 30) was determined along with the \% of 'liking' and that of 'disliking' responses against each item (Table 2). Further, the nature of responses was analyzed dimension-wise (Table 3).

Table 2:- Item-wise percentage analysis of respondents' liking and disliking.

\begin{tabular}{|c|c|c|c|c|}
\hline $\begin{array}{l}\text { item } \\
\text { S }\end{array}$ & statements & $\begin{array}{c}\text { rank } \\
\text { achieved }\end{array}$ & $\begin{array}{l}\% \text { of } \\
\text { liking }\end{array}$ & $\begin{array}{c}\% \text { of } \\
\text { disliking }\end{array}$ \\
\hline 1 & I could speak fluently in English & 20 & 68.94 & 31.06 \\
\hline 2 & $\begin{array}{l}\text { Before writing something in English, I would not have to } \\
\text { think it first in my mother tongue }\end{array}$ & 26 & 48.71 & 51.29 \\
\hline 3 & I could get a handful of reference books & 09 & 89.23 & 10.77 \\
\hline 4 & I could express my feelings in English & 14 & 81.18 & 18.82 \\
\hline 5 & I could not fumble if I am to speak in English & 18 & 72 & 28 \\
\hline 6 & It will help me in higher study & $\mathbf{0 2}$ & 96.71 & 3.29 \\
\hline 7 & It will help me in future career entrance test & 12 & 86 & 14 \\
\hline 8 & $\begin{array}{l}\text { I would overcome the feeling of inferiority for being a } \\
\text { student from Bengali medium school }\end{array}$ & 19 & 70.35 & 29.65 \\
\hline 9 & It will help me get good scores in examinations & 11 & 86.59 & 13.41 \\
\hline $\mathbf{1 0}$ & I could protect my self-esteem & 22 & 64.27 & 35.73 \\
\hline 11 & $\begin{array}{l}\text { I could communicate fluently in English with any English } \\
\text { speaking person }\end{array}$ & 23 & 63.76 & 36.24 \\
\hline 12 & $\begin{array}{l}\text { Being fluent in Bengali as well as in English I will be } \\
\text { confident enough in day to day practices }\end{array}$ & 07 & 91.76 & 08.24 \\
\hline 13 & It will develop my communicative skills in English & 01 & 97.41 & 2.59 \\
\hline 14 & It will help me to get information through ICT mode & $\mathbf{0 3}$ & 95.53 & 4.47 \\
\hline 15 & $\begin{array}{l}\text { I would feel much comfortable to interact with the } \\
\text { foreigners }\end{array}$ & 08 & 90.35 & 9.65 \\
\hline 16 & I could chat / interact confidently in English & 17 & $\mathbf{7 5 . 5 3}$ & 24.47 \\
\hline 17 & $\begin{array}{l}\text { I earnestly require English as the medium of instruction } \\
\text { in my school }\end{array}$ & 05 & 94.16 & 5.84 \\
\hline 18 & I could write anything in English in style & 16 & 76 & 24 \\
\hline-19 & I would know well neither my mother tongue nor English & 30 & 16.24 & 83.76 \\
\hline-20 & $\begin{array}{l}\text { If I go for English medium now, the achievement scores } \\
\text { will be less as a whole }\end{array}$ & 29 & 25.41 & 74.59 \\
\hline
\end{tabular}




\begin{tabular}{|c|c|c|c|c|}
\hline 21 & I could be able to think in English & 13 & 85.18 & 14.82 \\
\hline 22 & $\begin{array}{l}\text { I would feel shy for not speaking well in my mother } \\
\text { tongue }\end{array}$ & 27 & 47.29 & 52.71 \\
\hline 23 & $\begin{array}{l}\text { I could be able to understand clearly and with ease if } \\
\text { somebody speaks in English }\end{array}$ & 15 & 79.59 & 20.41 \\
\hline 24 & $\begin{array}{l}\text { If I could read, write and speak in English well, it will } \\
\text { help my job selection from a wide range in future }\end{array}$ & 04 & 95.06 & 4.94 \\
\hline-25 & $\begin{array}{l}\text { I do not feel my selves smaller to do not speak English } \\
\text { properly }\end{array}$ & 21 & 66.12 & 33.88 \\
\hline 26 & $\begin{array}{l}\text { If I know and speak in English well, I would have no } \\
\text { problem in future as international traveler }\end{array}$ & 06 & 92 & 08 \\
\hline 27 & $\begin{array}{l}\text { I would feel happy to identify with those guys of English } \\
\text { medium schools }\end{array}$ & 25 & $\mathbf{5 9 . 5 3}$ & 40.47 \\
\hline 28 & $\begin{array}{l}\text { Fluency in English speaking skills would boost my self- } \\
\text { esteem }\end{array}$ & 10 & 88.47 & 11.53 \\
\hline-29 & $\begin{array}{l}\text { I do not speak Bengali without some intervening English } \\
\text { words }\end{array}$ & 23 & 63.76 & 36.24 \\
\hline 30 & $\begin{array}{l}\text { Had I not spoken in English, I will be unable to } \\
\text { participate in out-of-school national /international events }\end{array}$ & 24 & 60.94 & 39.06 \\
\hline
\end{tabular}

The findings (Table 2) in general indicated greater \% of 'liking' responses, and the greater mean score of 'liking' responses against each item pointed to the students' preference for English medium.

Table 3:- Dimension-wise percentage analysis (in round figure) of respondents' liking and disliking

\begin{tabular}{|c|c|c|c|c|}
\hline Serial No & DIMENSIONS & $\begin{array}{c}\text { rank } \\
\text { achieved }\end{array}$ & \% of liking & \% of disliking \\
\hline $\mathbf{1}$ & Fluency in speech & $\mathbf{1}$ & $\mathbf{9 7 \%}$ & $\mathbf{3 \%}$ \\
\hline $\mathbf{2}$ & Easy worldwide communication & $\mathbf{2}$ & $\mathbf{9 5 \%}$ & $\mathbf{5 \%}$ \\
\hline $\mathbf{3}$ & Helpful for higher education & $\mathbf{3}$ & $\mathbf{9 2 \%}$ & $\mathbf{8 \%}$ \\
\hline $\mathbf{4}$ & Boosting self esteem & $\mathbf{4}$ & $\mathbf{8 0 \%}$ & $\mathbf{2 0 \%}$ \\
\hline $\mathbf{5}$ & Conflict with the mother tongue & $\mathbf{5}$ & $\mathbf{4 9 \%}$ & $\mathbf{5 1 \%}$ \\
\hline
\end{tabular}

The findings (Table 2) revealed that the participant students from Bengali medium schools in West Bengal, irrespective of the nature of locality (rural and urban) and socio-cultural background, preferred English as medium of instruction because of 'Fluency in speech' (97\%), 'Easy worldwide communication' (95\%) and 'Help for higher education' $(92 \%)$ as these three dimensions achieved ranks $1^{\text {st }}, 2^{\text {nd }}$ and $3^{\text {rd }}$ respectively. Further, they $(80 \%)$ thought that speaking in English would boost their self-esteem too. However, the participant students were hesitant about the 'conflict with mother tongue' if they start speaking in English. The results (Table 2 and Table 3) had been graphically represented below through the 'bar graph' and 'pie chart' respectively. 


\section{Bar graph:-}
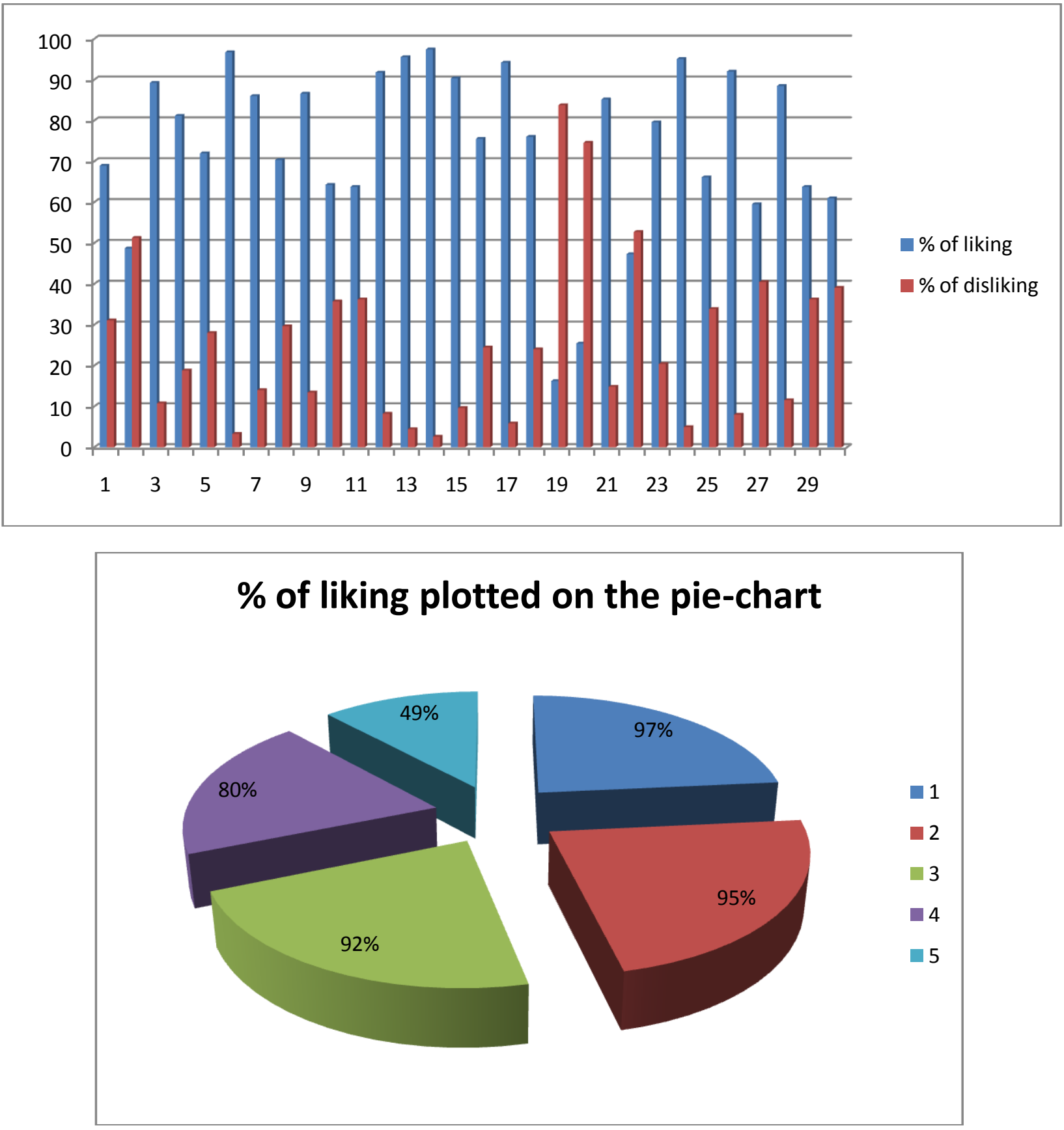

\section{Findings of the study:-}

1. There remained no statistically significant difference between the opinion of the participant students from Bengali-medium district-based rural schools and those of Kolkata metropolitan city of West Bengal in regard to preference for English as medium of classroom instruction.

2. Between the two responses indicating liking and disliking respectively, percentage of the responses pointing to liking was found greater than that of the responses pointing to disliking. This higher percentage of 'liking' responses revealed the fact that the majority of participant students preferred English as medium of classroom instruction though they were grown up in and habituated with the Bengali-medium school environment.

3. Their penchant for English medium was primarily due to 'fluency in speech' and 'easy worldwide communication'. With these two reasons, they also expressed the view that English-medium instruction at 
school level will also help them in future higher education. All these three dimensions of the opinionnaire pointed to above $90 \%$ liking responses.

4. Participant students viewed that being fluent in English speaking skills would raise their self esteem in social interactive environment. This dimension thus earned $80 \%$ positive responses.

5. Participant students were almost equally divided in opinion in regard to the issue whether speaking in English would generate any conflict between fluent usage of mother tongue or not.

Name of the student:

\section{The Opinionnaire}

\section{Name of the School:}

Class: IX

Age: $14+$ years

Bengalee Hindu

Instructions: "Dear student, we think that you have information about one recent development at the government level regarding medium of classroom instruction within the school like yours. Presently, the W.B. government has thought to introduce English as medium of instruction in the classroom of Bengali - medium schools. Now, as a junior high student of a Bengali medium school, what is your opinion regarding this? Do you like this change or not? Here are thirty statements concerning this issue. Each statement has two response categories - 'yes' and 'no'. Tick out 'yes' if you like the statement that means you prefer English as medium of instruction due to this cause, and tick out 'no' if you dislike it that means you do not prefer English as medium of instruction due to this cause. There is no right or wrong answers. Read the statement, think a bit and express your opinion by ticking out 'yes' or 'no'. Your thoughtful opinion will help our research. Now start your work. If you face any difficulty, do not hesitate to ask us."

N.B. The opinionnaire was prepared in Bengali language as all the participants were from Bengali-medium schools. For the reporting of research, the total matter had been translated into English.

\begin{tabular}{|c|c|c|c|}
\hline SI No & Statements & YES & NO \\
\hline 1 & I could speak fluently in English & & \\
\hline 2 & $\begin{array}{l}\text { Before writing something in English, I would not have to think it first in my } \\
\text { mother tongue }\end{array}$ & & \\
\hline 3 & I could get a handful of reference books & & \\
\hline 4 & I could express my feelings in English & & \\
\hline 5 & I could not fumble if I am to speak in English & & \\
\hline 6 & It will help me in higher study & & \\
\hline 7 & It will help me in future career entrance test & & \\
\hline 8 & $\begin{array}{l}\text { I would overcome e feeling of inferiority for being a student from Bengali } \\
\text { medium school }\end{array}$ & & \\
\hline 9 & It will help me get good scores in examinations & & \\
\hline 10 & I could protect my self-esteem & & \\
\hline 11 & I could communicate fluently in English with any English speaking person & & \\
\hline 12 & $\begin{array}{l}\text { Being fluent in Bengali as well as in English I will be confident enough in day to } \\
\text { day practices }\end{array}$ & & \\
\hline 13 & It will develop my communicative skills in English & & \\
\hline 14 & It will help me to get information through ICT mode & & \\
\hline 15 & I would feel much comfortable to interact with the foreigners & & \\
\hline 16 & I could chat / interact confidently in English & & \\
\hline 17 & I earnestly require English as the medium of instruction in my school & & \\
\hline 18 & I could write anything in English in style & & \\
\hline 19 & I would know well neither my mother tongue nor English & & \\
\hline 20 & If I go for English medium now, the achievement scores will be less as a whole & & \\
\hline 21 & I could be able to think in English & & \\
\hline 22 & I would feel shy for not speaking well in my mother tongue & & \\
\hline 23 & $\begin{array}{l}\text { I could be able to understand clearly and with ease if somebody speaks in } \\
\text { English }\end{array}$ & & \\
\hline 24 & $\begin{array}{l}\text { If I could read, write and speak in English well, it will help my job selection } \\
\text { from a wide range in future }\end{array}$ & & \\
\hline
\end{tabular}




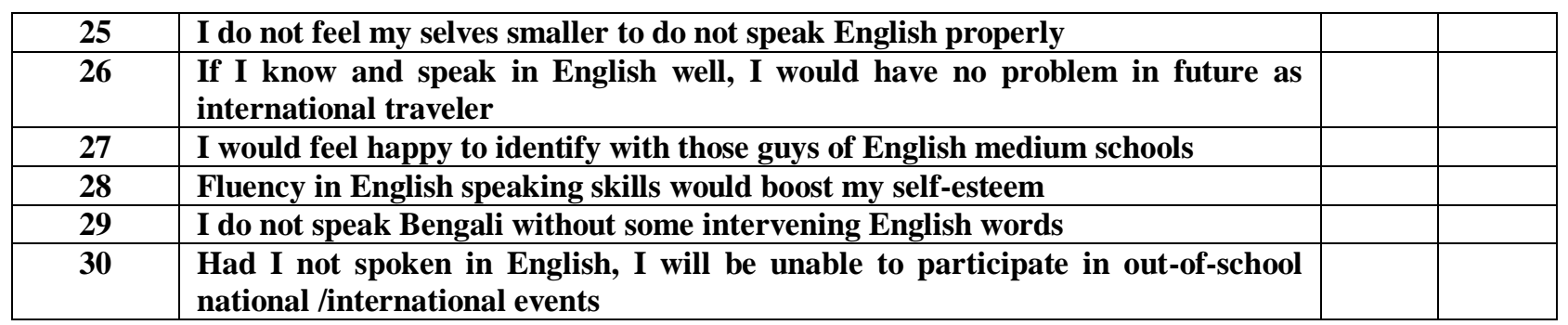

\section{Conclusion:-}

From the findings of the present study it can be concluded that the students of Bengali-medium schools under the WBBSE curriculum in the state of West Bengal prefer English as medium of instruction due to some definite causes.

\section{References:-}

1. Lo Yuen and Lo E S (2014). A Meta-Analysis of the Effectiveness of English-Medium Education in Hong Kong. Review of educational research, 84 (1), 47-73, Sage.

2. Lueg, K and Lueg, R (2015). Why Do Students Choose English as a Medium of Instruction? A Bourdieusian Perspective on the Study Strategies of Non-Native English Speakers. Academy of Management Learning \& Education, 14(1), 5-30.

3. Lueg, K (2015). English as a medium of instruction and internationalization at Danish universities: Status, perspectives, and implications for higher education executives. Communication and language at work, 1(4).

4. Shharifian, F (ed) (2009). English as an International Language: Perspectives and Pedagogical Issues. Multilingual Matters. Retrieved from ELT Journal http://eltj.oxfordjournals.org/content/64/3/347.extract on March, 2016.

5. The History of English (2011)

6. Retrieved from http://www.thehistoryofenglish.com/issues_global.html on March, 2016.

7. World Languages (2014) retrieved from https://www.daytranslations.com/world-languages on March, 2016. 